\title{
AÇORIANOS EM SAN CARLOS E A QUESTÃO DO OUTRO
}

\author{
Letícia Vieira Braga da Rosa ${ }^{1}$
}

Introdução

O Arquipélago dos Açores é formado por nove ilhas, localizadas no Oceano Atlântico, a cerca de $1600 \mathrm{~km}$ da costa portuguesa. Apesar de pertencer a Portugal, foi povoado a partir do século XV por diversos grupos étnicos. No século XVIII, ciclones, enchentes, terremotos, abalos sísmicos, erupções vulcânicas, somados à explosão demográfica, à escassez de terras e à falta de alimentos, levaram os açorianos a pedir ao rei permissão para emigrar (Wiedersphan, 1979).

Nessa mesma época, no sul do Brasil, a preocupação era com a constante ameaça de invasão espanhola. Como forma de proteger suas conquistas, Portugal decide povoar essas terras, iniciando um "programa de colonização organizada", com os habitantes do arquipélago dos Açores (Pesavento, 1999: 18).

Os açorianos enviados ao Brasil ficaram conhecidos como "Casais d'El Rey", pois receberiam da Coroa Portuguesa terras, ferramentas, alimentação e ajuda de custo em troca de guardar e defender o território português. Apesar da promessa, as disposições não foram integralmente cumpridas. Em 1761, um grande grupo de casais se encontrava ao redor da Vila de Rio Grande, ainda à espera de terras, quando ressurge o estado de guerra entre Portugal e Espanha (Pesavento, 1992) ${ }^{2}$.

Em abril de 1763, o general e governador de Buenos Aires, D. Pedro Cevallos, em nome de Carlos III, rei de Espanha, invade a capitania de São Pedro e conquista a Vila do Rio Grande, que havia sido abandonada pelas tropas portuguesas. Em pânico, a população só percebe a necessidade de fugir quando os espanhóis já estão chegando (Cidade, 1948).

Segundo César (1970: 170), os colonos açorianos mais pobres foram os que mais sofreram as consequências da invasão: "Muitos desses colonos, surpreendidos em suas chácaras pelas tropas castelhanas, foram levados com suas famílias para a região de Maldonado ${ }^{3 \%}$.

\footnotetext{
${ }^{1}$ Universidade Feevale, Brasil.

2 Por ocasião da guerra dos Sete Anos, na Europa, em que Portugal e Espanha estavam em campos opostos (Pesavento, 1992).

${ }^{3}$ A região de Maldonado, localizada ao sudeste do Uruguai, era uma zona de fronteira aberta, lugar de trânsito e de tráfico, passagem e refúgio entre os territórios portugueses e espanhóis. Banhada pelo
} 
É esta história que este artigo se propõe a acompanhar, tendo como objetivo discutir o tensionamento das relações sociais na formação Vila de San Carlos, em Maldonado, Uruguai.

A fim de conhecer as relações de conflito e disputa entre esses grupos, adota-se a abordagem da Sociologia Compreensiva, seguindo a proposta de Max Weber (1979), de compreender os fenômenos históricos a partir dos indivíduos e suas ações sociais. Como quadro teórico de referência o estudo está ancorado em autores como Simmel (2006), Mead (1973), Park (1928) e Todorov (1999).

Visando a uma perspectiva interdisciplinar, buscando conhecer o individual impregnado no social, a pesquisa vale-se da proposta de Pesavento (1995), que sugere a estratégia do historiador que recolhe fragmentos em discursos e imagens que falam do passado, não se atendo somente à história oficial, mas investigando as manifestações e acontecimentos singulares que quebram a rotina da vida urbana, "os cacos, vestígios ou vozes daqueles que figuram na história como 'povo' ou 'massa' ou que se encontram na contramão da ordem" (Pesavento, 1995: 284).

Com base nessas orientações, busca-se relatar as histórias de San Carlos, durante o período analisado, de 1763 a 1778, descobrindo nos acontecimentos singulares que quebraram a rotina da vila, vestígios desse passado. Com este propósito, foram selecionados alguns registros documentais apresentados por Pagola (2007), que contribuem para a visualização das relações sociais desse grupo, denominado "Pobladores de San Carlos".

“As famílias iam contentes”: a viagem até San Carlos

Antes da tomada de Rio Grande, não há indícios de que Cevallos tivesse intenção de fundar San Carlos. Pagola (2007: 19) considera a dificuldade em conseguir “elemento humano" para povoar e defender a região como um dos fatores da criação do povoado. Para Fajardo (1977: 208), o grande número de pessoas que Cevallos teve a seu dispor, após a conquista de Rio Grande, era uma condição rara àquela época. Soma-se a isso o fato de o grupo trazer seus bens materiais e instrumentos de trabalho.

Estrada (2007) destaca a guerra com Portugal como o principal motivo dessa resolução de Cevallos, face à necessidade de abastecer com trigo e carne as tropas estacionadas em Maldonado, nos fortes de Santa Teresa e São Miguel e em Rio Grande.

Oceano Atlântico, constituía um porto alternativo ao de Montevidéu, onde também aportavam navios de comércio clandestino e piratas (Frega, 2003). 
Assim, contar com um povo de agricultores era uma grande vantagem, devido às dificuldades de obter mão de obra qualificada em uma região inóspita.

Fajardo (1977: 207) ressalta o caráter inusitado de utilizar prisioneiros portugueses para povoar terras pertencentes à Coroa Espanhola, formando um povoado cujos moradores eram súditos originários do Estado rival: “Arriscada, porém notável experiência político-sociológica, que ao final teve êxito".

O modo como ocorreu o translado de Rio Grande até Maldonado parece indicar a boa disposição dos açorianos em aceitar a migração. Conforme documentos enviados a Cevallos pelo Tenente Piccolomini, que acompanhava a viagem, Fajardo (1977) descreve o lento transcorrer do percurso, de cerca de $470 \mathrm{~km}$, em que as famílias iam caminhando, levando seu gado e seus pertences, enquanto as carretas "carregadíssimas" transportavam móveis, utensílios e instrumentos agrícolas. Apesar de enfrentar chuvas rigorosas e temperaturas muito baixas, "as famílias iam contentes e com muito desejo de chegar" (Piccolomini apud Fajardo, 1977: 210).

De Rio Grande, Cevallos deu ordens ao comando militar de Maldonado, a fim de que começasse os preparativos para instalar os açorianos; determinando que, quando as famílias chegassem a Maldonado, fossem acomodadas, bem tratadas e abastecidas com carne em abundância (Estrada, 2007).

\begin{abstract}
Como quero ver trabalhando bastante aos islenõs portugueses que ficaram neste povoado e nos campos da região; permiti que fossem com suas famílias para essas paragens; previno a V.M. que aos que chegarem a essa povoação (Maldonado) vá acomodando em ranchos aí mesmo ou nas imediações, para que fiquem com a maior comodidade possível, até que eu chegue e disponha outras ordens para seu estabelecimento (Cevallos apud Pagola 2007: 20, tradução nossa).
\end{abstract}

A expressão usada por Cevallos, "permiti” em vez de "ordenei”, parece indicar que havia entre os açorianos boa disposição de seguir viagem e instalar-se na região espanhola (Estrada, 2007).

Esse aspecto pode ser evidenciado na carta de 6 de abril de 1763, enviada à Cevallos pelo Alferez Fulgencio Alagón, comandante de Santa Teresa. Conforme Cevallos havia pedido, ele informa ter questionado as famílias que passaram por Santa Teresa, e que todas, unanimemente, afirmaram preferir seguir adiante a voltar ao que haviam abandonado (Fajardo, 1977: 211).

A chegada do primeiro grupo ocorreu em 18 de junho de 1763:

Participo a V. Exma. que no dia 18 deste mês, chegaram as tropas de carretas e as famílias Isleñas que V. Exma. envia para a Población Nueva, a cargo do Ajudante de Milícias D. Fernando Cosido, e indo até essa povoação, instruí ao dito Cosido do que já havia sido feito e o modo que se devia de seguir para fazer o que ainda faltava 
[...] amanhã vão todos cortar madeiras e palha para os ranchos que se há de fazer (Mendinueta apud Estrada, 2007, online, tradução nossa).

Em 30 de julho de 1763, Lázaro Mendinueta, responsável pela recepção e assentamento dos açorianos, relata ao General Cevallos que os isleños começaram a trabalhar nas terras. Acostumado a lavrar a terra, o grupo começou a preparar o solo para o plantio antes mesmo de terminar de erguer suas moradias (Fajardo, 1977).

Assim, nascia a Vila de San Carlos. Nos primeiros tempos, era conhecida como "Pueblo de los isleños", em alusão à origem de seus moradores, ou "Pueblo Nuevo", pelo fato de já existir na região uma povoação junto ao posto militar de San Fernando de Maldonado. ${ }^{4}$

Apesar da condição inicial de prisioneiros de guerra, a maneira como Cevallos concebe a formação da vila, o modo como é realizada a viagem e como são recebidos e instalados na nova povoação, são indicativos de que os migrantes deste grupo viajaram pacificamente, aceitando de forma voluntária esse deslocamento.

Embora fossem súditos da Coroa Portuguesa, nem todos os açorianos se viam estimulados a lutar por Portugal, especialmente depois de frustradas as promessas reais; decidindo-se pelo deslocamento ao território espanhol, na esperança de obter as tão sonhadas vantagens que os havia impulsionado a migrar para a América.

Segundo Frega (in Heinz; Herrlein, 2003: 136, tradução nossa), nesses casos, “a questão não era tanto o lugar de nascimento, mas sim a relação com o exército invasor, já que a zona de ocupação se convertia, inevitavelmente, em fonte de recursos e gratificações." Por ser uma região de fronteira, era comum esse tipo de "lealdades ambivalentes", situações em que optar entre o lugar de origem e o lugar de residência era uma questão de sobrevivência.

Tenha sido o translado forçado ou voluntário, a população que não havia fugido de Rio Grande durante a Invasão Espanhola foi dirigida à região de Maldonado, iniciando um novo processo de colonização que, associando migração a um período de guerra, ocasionou o estranhamento entre açorianos e espanhóis, dando lugar a tensões e rivalidades entre os dois grupos.

Cabe destacar que Weber (2000) aponta a migração como um dos elementos que levou a um novo modo de organização social, com características bastante singulares,

\footnotetext{
${ }^{4}$ Nem todas as famílias chegaram ao mesmo tempo. Às 40 famílias iniciais juntam-se outras, num lento fluir de meses e anos sucessivos. O censo de 1764 registra 130 famílias açorianas, que totalizavam 530 pessoas, decorrido apenas um ano da fundação da vila (Pagola, 2007).
} 
que aos poucos foi tomando lugar da forma comunitária. Tal sociedade, baseada em interesses racionais, modifica o convívio comunitário, exigindo novas relações sociais.

Fazendo a distinção entre comunidade e sociedade, Tönnies (in Miranda, 1995) apresenta dois conceitos distintos e antagônicos: Gemeinschaft e Gesellschaft. O conceito de Comunidade (Gemeinschaft) repousa sobre laços de sangue, parentesco, associações com a terra e laços de lugar, de amizade, intimidade, informalidade, crenças comuns e sentimentos partilhados, contrastando com o conceito de Sociedade (Gesellschaft), que é pública, formal e está baseada no contrato e nas relações funcionais. A sociedade representa a vida pública, a coexistência de indivíduos independentes entre si, o egoísmo, o modo como as relações sociais vão se complexificando, sendo abrangentes, ilimitadas e tendendo à extensão. "Na comunidade há uma ligação desde o nascimento, uma ligação entre os membros, tanto no bem-estar quanto no infortúnio. Já na sociedade, entra-se como quem chega a uma terra estranha" (Tönnies in Miranda, 1995: 231-2).

Assim, a vila de San Carlos vai surgir justamente no momento histórico em que os valores de comunidade (Gemeinschaft) começavam a dar espaço aos valores de sociedade (Gesellschaft); em que novos comportamentos iam, aos poucos, ocasionar um novo contexto: a vida moderna.

Carolinos e Fernandinos ${ }^{5}$ : a questão do outro

Procurando entender as práticas cotidianas a partir da interação entre indivíduos e sociedade, Mead (1973) propõe que se busque conhecer os atos do indivíduo em sua situação social. Sendo que o "eu" recebe influência dos "outros", o indivíduo está sujeito ao comportamento dos demais. O mundo é, portanto, um conjunto de referências que o "eu" divide com os "outros", o que leva a uma construção social da realidade que, em sua essência, é simbólica. Ao considerar o papel do outro, o indivíduo é sujeito de negociação com o entorno, respondendo a si mesmo da mesma forma como os outros lhe respondem. Na interação que se estabelece, cada ação provoca um estímulo para o outro e também para aquele que a iniciou, num processo de trocas e inter-relações, feitas de atrações, repulsões e tensões que caracterizam o processo de socialização.

Considerando esse processo de interação simbólica, cabe observar o relacionamento entre os açorianos de San Carlos e os outros grupos que circundavam a

\footnotetext{
${ }^{5}$ Gentílicos que designam, respectivamente, habitantes de San Carlos e San Fernando de Maldonado.
} 
região, enfatizando as relações que se estabelecem entre sujeitos que se referenciam e afetam mutuamente.

Tomando como referência o estudo elaborado por Todorov (1999) sobre a relação entre o "eu" e o "outro", cabe destacar o modo como, em grupos sociais com sistemas de valores, ideias e costumes diferentes, uma cultura distinta é percebida, aceita, criticada e assimilada, e o estranhamento que os valores de um grupo podem causar sobre os demais. O autor subdivide essa relação em diversas categorias com múltiplas direções, desde o outro que se descobre dentro de si mesmo até aquele que não se reconhece como sendo da mesma espécie.

De uma perspectiva interna, para os membros de uma cultura, o "outro" é todo aquele que, embora pertencendo ao mesmo grupo social, apresenta diferenças em relação ao "eu", sejam sexuais, ideológicas, econômicas ou comportamentais, como os homens em relação às mulheres, os adultos em relação às crianças, os ricos em relação aos pobres, os loucos em relação aos 'normais'. De uma visão externa, o "outro" é todo aquele que está fora do grupo social ao qual o "eu" faz parte, “[...] uma outra sociedade que, dependendo do caso, será mais próxima ou longínqua: seres que em tudo se aproximam de nós, no plano cultural, moral e histórico, ou desconhecidos, estrangeiros cuja língua e costumes não compreendemos, tão estrangeiros que cheguemos a hesitar em reconhecer que pertencemos a uma mesma espécie" (Todorov, 1999: 4).

Desse modo, as relações entre os açorianos e os espanhóis atendem à problemática do "outro" exterior. Mais do que diferentes, cada grupo percebia o outro como inimigo, reproduzindo e reforçando, em solo americano, antigas inimizades dos dois países europeus. Mesmo que, devido ao Tratado de Paris, Portugal e Espanha não estivessem mais em guerra, nas colônias da América a disputa entre os dois povos prosseguia. Embora com o tempo os dois grupos passem a integrar uma mesma comunidade, no início o povo açoriano de San Carlos era tratado com desconfiança, como o outro, o diferente, los isleños, o estrangeiro.

Essa noção do outro se aproxima à do estrangeiro, formulada por Simmel (2005), visto como um estranho, um não proprietário do solo. "O estrangeiro por sua natureza não é proprietário do solo, e o solo não é somente compreendido no sentido físico, neste caso, mas, também, como uma substância delongada da vida, que não se fixa em um espaço específico, ou em um lugar ideal do perímetro social" (Simmel, 2005: 266). 
Para Simmel (2005), o estrangeiro é sempre avaliado como alguém de fora, como um não pertencente, um não membro do grupo, fazendo com que as relações se estabeleçam com um certo distanciamento, mesmo quando sua vida esteja condicionada por essa sociedade.

Considerados como estrangeiros devido a sua origem lusa, as relações dos carolinos com os demais moradores da região vão-se dar a partir de um parâmetro de distanciamento. Desse modo, embora "pobladores fundadores" da vila, os açorianos eram vistos como não pertencentes à região, definida social e politicamente como espanhola.

Segundo Todorov (1999: 90), “a primeira reação espontânea em relação ao estrangeiro é imaginá-lo inferior, porque diferente de nós.” Mead (1973: 241) destaca o fato de que o estrangeiro, por ser diferente, é alguém que leva o grupo a uma conduta de proteção, mantendo-se à distância, no isolamento. Simmel (2005) define essa relação que se estabelece como um "não relacionamento":

$\mathrm{Na}$ relação com um 'estrangeiro' ou 'estranho' [...] o que existe é um nãorelacionamento. Nos contatos possíveis ele, o estranho, é sempre considerado como alguém de fora, como um não membro do grupo, portanto, as relações se dão a partir de um certo parâmetro de distanciamento objetivo, mas partindo das características essenciais de que também ele é um membro de um outro determinado grupo (Simmel, 2005: 270).

A noção de estrangeiro proposta por Simmel (2005: 265) não se refere ao seu uso no sentido habitual, “em relação àquele que vem hoje e amanhã se vai, mas como o que vem hoje e amanhã pode permanecer - porque era possível se mover e, embora não siga adiante, ainda não superou completamente o movimento do ir e vir". Nesses termos, sua posição é determinada culturalmente, envolvendo ao mesmo tempo distância e proximidade. Pelo fato de ter vindo de fora e não pertencer à região, não partilhando sua história e seus valores, mesmo estando geograficamente próximo, o estrangeiro é percebido como distante.

Vindos de fora, com a finalidade de formar uma nova povoação, os açorianos encontraram-se circunscritos a uma região culturalmente diferente. Além disso, chegavam na condição de vencidos, conquistados, ou seja, em uma posição de inferioridade. Mesmo sendo chamados "vecinos", isto é, moradores, são observados com estranhamento e desconfiança, como ainda pertencentes a um outro grupo que, além de diferente, era tido como rival. Essa condição fica manifesta até mesmo no modo como é denominada a vila: "pueblo de los isleños". 
Observe-se que, da mesma forma que os pertencentes à Coroa Portuguesa portugueses, paulistas, lagunenses e açorianos - tinham origens diversas, também os grupos espanhóis procediam de locais distintos, sendo divididos por Frega (in Heinz; Herrlein, 2003: 122) em "españoles europeus", como os canários (vindos das ilhas Canárias) e espanhóis (procedentes da Espanha); e "españoles americanos", isto é, nascidos em solo americano, como os montevideanos (nascidos em Montevidéu) e porteños (da região de Buenos Aires). No que se refere à multiplicidade de origens dos habitantes da região de Maldonado, a autora também cita a existência de ingleses, franceses, indígenas e africanos.

Para conhecer o modo como as relações entre grupos étnicos diferentes podem levar à atração ou repulsa, foram pesquisadas as relações de poder e o modo como fatores econômicos, políticos e culturais influenciaram na formação de San Carlos. Com base nesses aspectos, foram selecionados dois elementos de análise: a agricultura, marcada pela contenda do trigo, e a linguagem, com o uso de idiomas distintos.

Os trigais carolinos: disputas e relações de poder

O fato de os dois grupos, povo de San Carlos e povo de Maldonado, verem o mundo através dos valores e costumes da sua cultura de origem, tomando como referência, respectivamente, Portugal e Espanha, trouxe como consequência a propensão de cada um utilizar o seu modo de vida como critério para julgar o que é correto. Quanto mais um grupo conhece ou ignora a identidade do outro, maior a tendência à aproximação ou ao distanciamento, assumindo uma postura de fraternidade ou de hostilidade, antagonismos e resistências. Segundo Weber (2000: 272), a crença do colonizador na afinidade com seu grupo de origem leva à "convicção da excelência dos próprios costumes e da inferioridade dos alheios."

De acordo com Todorov (1999: 75), a postura da distância e do julgamento podem levar "facilmente ao sentimento de superioridade." Observando o modo como se formou San Carlos, pode-se perceber essa situação. Mesmo longe do solo europeu, os dois grupos - carolinos e fernandinos - continuam a representar seus países de origem, vendo-se como portugueses/açorianos ou espanhóis e repetindo a situação de estranhamento de um grupo sobre o outro. Para Mead (1973: 231), o sentimento de superioridade pode se tornar exagerado no patriotismo com que um indivíduo se identifica com o grupo. Considerando o estado de guerra que motivou a formação da 
vila, a vinda dos açorianos a San Carlos, derivada de uma ação que mistura migração e guerra, contribuiu para a visão de superioridade dos espanhóis sobre "los isleños".

Tão logo surge o povoado, vão aparecendo as diferenças entre os moradores de San Carlos e os de Maldonado. O distanciamento entre os dois grupos se evidencia pela desconfiança dos espanhóis com relação aos açorianos, pois mesmo formando com eles um novo povoado, estes eram constantemente vigiados a fim de garantir a submissão.

Cabe apresentar o conceito de poder proposto Weber (2000: 33). "Poder significa toda probabilidade de impor a própria vontade numa relação social contra resistências, seja qual for o fundamento dessa probabilidade." $\mathrm{O}$ autor destaca a dominação como um caso especial de poder que envolve a possibilidade de impor a própria vontade ao comportamento de terceiros. Ligada à autoridade, poder de mando e dever de obediência, a dominação implica uma relação social de poder desigual, em que um lado comanda (domina) e o outro obedece, estruturando as relações de poder a partir de duas posições: dominador e subordinado/dominado. $\mathrm{O}$ autor considera a dominação como legítima apenas quando reconhecida e aceita pelos dominados, diferentemente, denomina como associação política, as situações de dominação baseadas em ordens, nas quais os "dirigentes servem-se de todos os meios possíveis para alcançar seus fins", inclusive a ameaça e a coação física (Weber, 2000: 34).

O modo como a vila foi configurada, sob o comando político, jurídico e militar de Maldonado, indica o caráter de exclusão dos açorianos nas decisões do povoado. Assim, na organização de San Carlos, aos espanhóis coube o comando militar e administrativo da vila. Já, aos açorianos coube o trabalho braçal, em especial o trabalho no campo.

A agricultura garantiu aos açorianos uma vida confortável, poucos anos depois de instalados na vila, fato que motivou o abuso do poder espanhol, com o confisco de parte das colheitas açorianas, gerando ainda mais pontos de conflito entre os grupos. Segundo Fajardo (1953: 30) o trigo estava associado à essência da vila de San Carlos, "ao mais íntimo e profundo da sua vida, como se em seu sentido vital os açorianos projetassem as alegrias e pesares de sua história”. 
Os trigais carolinos estão ligados a vários momentos significativos desses primeiros tempos. É pelo trigo que a vila prosperou, pelo trigo que se conhece o número de seus moradores ${ }^{6}$, pelo trigo que surgiram novos problemas.

Comparando os moradores de San Carlos a seus vizinhos de Maldonado, Assunção (1978) diferencia os dois grupos, considerando sua cultura de origem, respectivamente portuguesa e espanhola, apontando o apego à terra e ao seu trabalho. Nesse ponto, para os espanhóis, a agricultura era vista com desprezo; para os açorianos, o trabalho no campo era valorizado.

Este fenômeno de apego à terra e seus ofícios, que diferencia os portugueses dos espanhóis, está esplendidamente tipificado em nosso território, entre Maldonado e San Carlos dos primeiros tempos. A primeira sendo a população mais antiga, a segunda, formada por açorianos internados por Cevallos depois da tomada de Rio Grande [...] em poucos anos supera aquela em riqueza, em colheitas abundantes, em indústrias etc. (ASSUNÇÃO, 1978: 157).

Segundo Novais (2005), enquanto os portugueses buscaram garantir a posse por meio do povoamento, estabelecendo uma colonização baseada na agricultura, na América espanhola, devido à riqueza mineral das terras ocupadas, a colonização dedicou-se à mineração. Somente onde não era possível a exploração de minérios é que a colonização passou a se ocupar da produção agrícola. Esse aspecto pode ser evidenciado na análise da situação dos povos rio-platenses realizada por Pedro Rodríguez Campomanes, então ministro de Carlos III da Espanha, que indicava a falta de cuidado com a agricultura e a pecuária, percebidas pelos espanhóis como trabalhos pouco nobres, como uma das razões da pobreza na região (Estrada, 2007). Orientados pela visão de conquista e exploração dos recursos minerais, os espanhóis se reservavam às ações de comando, destinando as tarefas de execução aos povos conquistados.

A delegação dos trabalhos de execução aos isleños fica evidenciada logo na criação do novo povoado, quando Cevallos expressa "como quero ver trabalhando bastante aos islenõs portugueses" (Cevallos apud Pagola, 2007: 20).

Segundo Assunção (1978: 191), por ter sido povoada por um grupo com tradição na agricultura, San Carlos se tornou um "caso único" de sucesso agroindustrial, com "fruticultura abundante; semeadura de trigo e linho cânhamo de alto rendimento; vinhas; e indústria de leite e queijo". Fajardo (1977) ressalta que apesar de ter havido tempos difíceis, como a safra de 1770 , em que não conseguiram colher nem mesmo a

\footnotetext{
${ }^{6}$ Em maio de 1764 a vila recebe as primeiras sementes de trigo enviadas por Cevallos de Montevidéu. Buscando repartir equitativamente as sementes, foi realizado um "rústico censo", no qual são registrados os chefes de família e o respectivo número de filhos. (Fajardo, 1953).
} 
quantidade de grãos plantados; San Carlos prosperou devido ao trabalho de seus moradores, tornando-se um importante centro econômico e adquirindo fama por seus trigais.

Poucos anos depois de instalados na região, os açorianos superaram a riqueza da vila de Maldonado, apresentando prósperas indústrias e abundantes colheitas. A vila se transforma em celeiro da região, passando seus moradores a viver tempos de fartura. Essa condição de desenvolvimento, fez com que San Carlos, em muitos momentos, sofresse com o abuso do poder espanhol, que recolhia para seu próprio uso parte do trigo das colheitas e da lenha cortada pelos açorianos (Fajardo, 1997).

Outro fator que distinguiu as duas vilas está ligado à finalidade com que cada uma foi criada. Enquanto San Fernando de Maldonado se formou como posto militar, San Carlos foi planejada por Cevallos como ponto de abastecimento, a fim de suprir especialmente com trigo e carne as tropas de Maldonado, Rio Grande e os fortes de Santa Teresa e São Miguel. Embora pela legislação espanhola o título de "vila" indicasse autonomia, San Carlos, apesar de constituída como vila, tinha seu comandante, Fernando de Cossio, subordinado à autoridade do comandante de Maldonado, Lucas Infante, fato que contrariava as indicações da "Leis das Índias" 7 (Pagola, 2007: 21).

Sujeitos às autoridades de Maldonado, a quem deviam pedir permissão de ir e vir, os açorianos estavam sob constante vigilância. Em sua posição de domínio, Cevallos chega a ordenar que, se alguém fosse pego saindo do lugar, caso fosse considerado perigoso, devia ser enviado para Montevidéu (Pagola, 2007).

Visando fixar o grupo na região, ainda no primeiro ano de formação da vila, Cevallos manda instruções prevenindo às autoridades que não autorizem aos isleños a ir para Montevidéu ou a nenhuma outra parte até que não tenham suas casas fabricadas, estejam bem estabelecidos e sejam de confiança (Estrada, 2007).

Por muito tempo, a vida dos açorianos transcorreu sob o impacto dessas contrariedades, derivadas dos excessos, suspeição, falta de prudência e até "ciúmes" por parte dos Comandantes de Maldonado, instigando ressentimento e revolta dos moradores de San Carlos frente às arbitrariedades cometidas pelos espanhóis. Mescla de interações e tensões, proximidade e distância, autoridade e submissão, as relações que se estabeleciam, estavam comprometidas pela rivalidade e mútua desconfiança (Ibid). ${ }^{7}$ São chamadas "Leis das índias" os dispositivos que regulamentavam a descoberta e o povoamento na
América Espanhola. 
Essa condição pode ser ilustrada nas determinações oficiais sobre a comercialização da colheita: o trigo plantado devia abastecer primeiro às guarnições espanholas, sendo que o restante somente podia ser vendido a quem as autoridades indicassem. Confirma essa resolução a proibição de Cevallos de que vendessem a sobra de suas colheitas a outras praças que não fosse a de Rio Grande. Embora Fajardo (1953: 58) ressalve que a medida indicava o cuidado do governador com a Vila, procurando favorecer os moradores do "Povo Novo" e evitar a concorrência que podiam ter em Montevidéu e Buenos Aires - ordenando ao comandante de Rio Grande que comprasse o trigo da vila com igualdade de condições -, o fato confirma a situação de submissão vivida pelos açorianos, sem autonomia para decidir sobre o produto de seu trabalho.

Em outra situação, 38 agricultores de San Carlos vendem trigo ao Rei para abastecer Rio Grande e não recebem pagamento. Com origem nesses episódios, um somatório de fatores vai ampliando a animosidade entre os dois grupos.

Em 1766, cansados dos abusos cometidos por Lucas Infante, comandante de Maldonado, os açorianos escrevem ao novo governador do Río de la Plata, Francisco de Paula Bucareli y Ursua, reclamando que o comandante confiscava-lhes parte do trigo e da lenha para seu próprio uso. Em represália, Infante tenta expulsar da vila as famílias dos responsáveis pela denúncia. Nesta ocasião, a intervenção do governador Bucareli mostrou-se favorável aos açorianos, decidindo que, para poder expulsar as famílias consideradas prejudiciais, era indispensável que todos os moradores estivessem de acordo e, enquanto isso, não deveria ser tomada nenhuma atitude contra elas (Estrada, 2007).

Acentuando esses conflitos e rivalidade, o constante estado de guerra na região reforçava a visão do outro como estrangeiro, rival, inimigo. Em 1767, temendo uma invasão portuguesa para retomar Rio Grande, Maldonado se prepara para uma possível ameaça lusitana, vigiando San Carlos com maior rigor. Segundo Estrada (2007), a situação havia ficado ainda mais tensa, aumentando a desconfiança sobre os açorianos. As instruções militares recomendavam que não fosse permitido entrar na vila algum português ou cartas ou qualquer outro meio de comunicação, pois não faltariam mal intencionados tentando seduzir os isleños a voltar a terras de Portugal.

Em 1769, em meio a uma crise na agricultura, novamente os moradores de San Carlos reclamam ao governador do novo comandante de Maldonado, Bartholomé Ferro, denunciando o modo como eram tratados. 
O ano passado nos atropelou o senhor comandante e usando a força de sua tropa, nos tirou todos os grãos e demais coisas, não ficando lugar algum em nossos ranchos sem ter sido revistado (até debaixo da cama), armazenando os grãos no Quartel, sem medida e sem pagamento, de onde não se sabe qual destino foi conferido ao que arrancou com tanto vigor... (Fajardo, 1953: 151, tradução nossa).

Em represália, ao ficar sabendo das acusações, o comandante Ferro vai até a vila, fazendo comparecer a sua presença todos os que haviam assinado a denúncia. Devido à violência do processo, a maioria dos moradores se retratou, recaindo as represálias sobre os líderes do movimento, que foram presos e tiveram seus bens confiscados. Aqui se percebe novamente a visão de superioridade do conquistador sobre o conquistado, do natural com relação ao estrangeiro, sendo utilizada como justificativa para atos de violência. Este fato também indica a resistência açoriana, não aceitando subordinar-se aos espanhóis.

A definição e controle do território, a apropriação dos recursos do lugar e o gozo de privilégios são apontados por Frega (in Heinz; Herrlein, 2003) como base dos conflitos e rivalidade entre vilas situadas tão próximas como San Carlos e Maldonado. Entretanto, conforme foram adquirindo maior prosperidade, passando de agricultores a comerciantes e, inclusive, estabelecendo pequenas indústrias, a busca por autonomia dos moradores carolinos foi aumentando. Analisando a situação, Fajardo (1953: 191, tradução nossa) conclui: "a verdade é que San Carlos, aos seis anos de seu nascimento, queria escapar da autoridade excessiva do comando político-militar de Maldonado.”

Além da situação de domínio de Maldonado sobre San Carlos, outro aspecto a ser ressaltado refere-se ao fato de que os açorianos, por sua vez, acabavam reproduzindo o papel de poder e superioridade sobre um terceiro grupo que aparece na formação da região: os escravos africanos. Forma-se, assim, um esquema de reprodução de relações de poder, em que os açorianos exerciciam domínio sobre seus escravos enquanto estavam eles mesmos sob a dominação dos espanhóis.

Observe-se que, também, a comunidade indígena estava sujeita à relação de dominação. Na época em que os açorianos se estabeleceram em San Carlos, a região era habitada pelos índios da tribo dos benguaes e charruas (Pintos, 1975). Os registros paroquiais de San Carlos apresentados por Pagola (2007) também atestam a existência de índios provenientes do Brasil, da região das Missões, do Paraguai e de Rio Grande.

Segundo Todorov (1999: 175), embora a visão do outro como diferente e, portanto, inimigo, tenha sido a base de todas as invasões, conquistas e colonizações da história, na conquista e colonização da América, o contraste entre a colônia e a 
metrópole, com a relativização dos valores morais, levou ao massacre e extermínio de povos indígenas, vistos como inferiores, "a meio caminho entre os homens e os animais".

Assim, as relações sociais, condicionadas pela opressão e submissão, tensões e desconfiança, revolta e resignação, atestam que, ao mesmo tempo em que se encontravam sob o domínio dos espanhóis, os açorianos estabeleciam seu poder sob os escravos africanos e os indígenas que habitavam a região.

Pelos documentos existentes, pode-se perceber que, mesmo integrando o núcleo povoador da vila, escravos aparecem de maneira anônima, como bens deixados em testamento. Pagola (2007: 258, tradução nossa), afirma que os escravos "figuram anonimamente na lista das famílias que o Vice-rei Cevallos envia desde o Rio Grande com destino ao novo povoado. Considerados como bens, como objetos, aparecem incluídos entre os inúmeros pertences que eram trazidos." Vistos como tão diferentes que não podiam ser reconhecidos como pertencentes à mesma espécie, africanos e indígenas eram tomados como objetos vivos, sem vontade própria, desprovidos de emoções e razão e, portanto, passíveis de submissão.

Segundo Pesavento (1986: 22), a escravidão tem como forma a coerção baseada meramente na violência, "anulando-se a figura do escravo enquanto indivíduo, ao qual é negado a humanidade. O escravo não é dono do seu trabalho ou de si próprio e não tem outra opção senão trabalhar ante a permanente ameaça de força física que sobre ele se exerce."

Além da situação de dominação, cumpre ainda referir-se às relações de parentesco que se desenvolviam entre escravos e senhores na vila de San Carlos. Exemplo dessa situação é o caso do testamento de Manuel Antonio Dutra Gómez e María Josefa Suárez o qual prometia a liberdade da escrava María Rosa e suas duas filhas, Fulgencia e Mercedes, como "prêmio por sua honradez e cuidado com que lhes havia servido". O documento estabelecia que as três ficassem livres após a morte de seus amos, atribuindo aos herdeiros de Manuel Antonio e María Rosa a responsabilidade de zelar pelas filhas da escrava. Pelo teor do texto, embora de modo velado, pode-se inferir a existência de uma relação de parentesco encoberta entre as partes, pois que os herdeiros ficaram incumbidos de cuidar da educação das filhas da escrava e, na falta de sua mãe, por impedimento físico ou incapacidade, velar pelas duas, "abrigando-as e tratando-as como irmãs" (Pagola, 2007: 253, tradução nossa). 
Embora as relações sexuais se efetivassem e, muitas vezes, fossem evidentes, a diferença percebida entre um e outro grupo não permitia que esses parentescos fossem assumidos claramente em público, resultando em expressões dúbias como "tratando-as como irmãs", acima citada.

Park (1928) observa que, mesmo nos casos de escravidão, a assimilação de um grupo ao outro acaba sendo inevitável. Povos e raças destinados a viver juntos, inevitavelmente se misturam e as relações que eram meramente econômicas ou políticas se tornam sociais e culturais. "Com o tempo, povo dominante e povo submetido acabam se tornando partes integrais da sociedade" (Park, 1928, online, tradução nossa).

Após investigar como as relações de poder e o modo como os fatores econômicos e políticos estabeleceram a tensão entre os grupos, cabe observar como as diferenças culturais ocasionaram conflitos e disputas e, também, ajustes e adaptação, analisando as diferenças linguísticas dos primeiros tempos do povoado.

Linguagem e adaptação: De "casais d'El Rey" a "Pobladores de San Carlos"

Segundo Mead (1973: 167), o processo da linguagem é essencial para o desenvolvimento do indivíduo em suas relações com os outros. Mas, ao mesmo tempo em que ajuda a reforçar a unidade interna do grupo, o idioma pode ser também um forte sinal de estranhamento e dificuldade de comunicação com o outro.

Esse aspecto fica evidenciado nos registros de batismo, casamento e óbito, apresentados por Pagola (2007), em que se observa a tradução de nomes e sobrenomes portugueses, transformando João em Juan, Paulo em Pablo, André em Andrés, Margarida em Margarita, Conceição em Concepción, Maria do Carmo em Maria del Carmen, D’Utra em Dutra, Fernandes em Hernandez, Peixoto em Pichoto, Teixeira em Techera. Essa mudança do nome pode ter influenciado também, entre outros aspectos, à desconstrução da identidade luso-açoriana.

Além das traduções, com a mudança de grafia, um mesmo sobrenome acabava sendo escrito de diversos modos. Uma mesma família de sobrenome Piriz, por exemplo, pode se transformar em Píriz, Pírez, Peres, Perez. Do mesmo modo, o sobrenome Teixeira encontra-se grafado de diversas formas: Texeira, Teyxeyra, Teixeyra, Techeira, Techeyra, Techera. Essa dificuldade de conciliar os idiomas levou a casos como o de Benito Lopes que passou a ser chamado de Bento Lópes, Bentos López, Ventos López.

Há casos em que pessoas de uma mesma família apresentam diferentes grafias do sobrenome, o que gera confusão e dificuldade em identificar os laços de parentesco. 
Veja-se a família de Manuel José Gómez Santos, procedente de Santa Maria, Açores. Filho de Manuel Gómez e Elena de la Resurrección Santos, Manuel José casou-se com Rosa de la Fuente, filha de Francisco Fonte e Esperanza Fonte. Neste caso, pode-se assinalar a mudança do sobrenome Fonte para "de la Fuente" e a mudança do sobrenome Gomes para Goméz e também "Pomes” (Pagola, 2007).

Assim, a modificação dos nomes, traduzidos do português ao espanhol, marca a mudança da identidade de "casais d'El Rey" a "Pobladores de San Carlos". Essa alteração nos nomes e sobrenomes também assinala um aspecto de adaptação do grupo açoriano frente à linguagem e aos costumes espanhóis.

Outro aspecto que causa dificuldade para identificar as relações familiares refere-se ao modo como são registrados os sobrenomes na Espanha e em Portugal. Enquanto que em Portugal o sobrenome da mãe precede o do pai, o costume espanhol é nominar primeiramente o sobrenome paterno, o que gerou mais confusão nos registros carolinos (Pagola, 2007: 12)

Assim, um dos desafios dos dois grupos foi o de alcançar o entendimento e criar vínculos, superando diferenças culturais e encontrando pontos de adaptação. Park (1928) assinala os períodos de guerras e os processos migratórios como momentos decisivos da história da humanidade, que levam os homens a uma convivência que mescla competição, conflito e cooperação, consequência do contato e da comunicação entre grupos diferentes, estabelecendo relações pelo intercâmbio de conhecimento e experiências. O autor cita o conflito como característica da imigração em seu período de transição, em que velhos hábitos vão se desfazendo e novos vão se formando, permitindo a adaptação e assimilação cultural.

Mead (1973) considera a linguagem como um processo de interação social, que inclui uma atitude cooperativa a fim de que haja entendimento entre os indivíduos. Assim, a compreensão do idioma do outro passa a ser basilar, embora em San Carlos dos primeiros tempos o idioma utilizado fosse o português. Tão logo chegaram, os açorianos solicitaram um professor que falasse o idioma castelhano. Quintana (2011) identifica essa renúncia à língua materna como "um claro exemplo de expressão coletiva que aponta para projetos comuns. [...] mais do que uma renúncia é uma forma inteligente de adaptação ao meio.”

Assim, o fato de possuírem idiomas diferentes pode ser visto como uma barreira que, no período inicial, dificultou o entendimento entre carolinos e fernandinos. Entretanto, apesar de todas as diferenças e tensões entre os dois grupos, quer parecer 
que, a linguagem foi utilizada como um ponto de adaptação dos açorianos aos espanhóis. Pois, embora a linguagem possa, em um primeiro momento, ser motivo de diferenciação cultural, ao se necessitar uma atitude cooperativa, ela favorece o processo de adaptação e assimilação entre os grupos.

Chegar e partir: San Carlos se despovoa

Em 1776 a vila de Rio Grande foi retomada pelos portugueses e no ano seguinte um novo tratado alterava as linhas de fronteira. Assinado em 1777, o Tratado de Santo Ildefonso ${ }^{8}$ determinava que as terras do Rio Grande do Sul, que estavam em poder da Espanha, deveriam voltar a pertencer a Portugal.

Com isso, muitos açorianos partiram de San Carlos, retornando a terras portuguesas, para povoar as novas zonas demarcadas. Segundo Fajardo (1953), o regresso inicial de 40 famílias, como resultado do Tratado mencionado, deixou a vila com um aspecto desolador, pois os moradores que resolveram ficar em San Carlos tiveram de ir para o campo atender aos estabelecimentos, às chácaras e às estâncias abandonadas pelos que partiram, o que demandou, também, uma nova repartição de terras.

A busca por novas propriedades; a não adaptação ao território espanhol; os estados de guerra, inimizades e questões políticas; foram fatores que levaram muitas famílias açorianas à decisão de voltar ao solo português. No ano de 1778, "San Carlos se despovoa" (Pagola, 2007: 23, tradução nossa). Começava, lenta e progressivamente, a saída dos açorianos e "a vila de San Carlos perde grande parte de seu potencial humano" (ibid).

Os açorianos que resolveram permanecer parecem ter sido aqueles que melhor se adaptaram ao meio, "reconhecendo a si mesmos como parte integrante desse conjunto que é a Vila e demonstrando pertencer a ela, o que se traduz em termos de identidade coletiva" (Fajardo, 1953: 209, tradução nossa). Pode-se apontar que as famílias que conseguiram superar conflitos e constituir vínculos sociais tiveram maior facilidade de adaptação, decidindo-se a ficar em San Carlos. Já, aquelas que tiveram dificuldade de estabelecer vínculos com a comunidade espanhola, conservando-se na

\footnotetext{
${ }^{8}$ O Tratado de Santo Ildefonso foi acordado em 1777 entre as duas Coroas Ibéricas, destinando a Colônia de Sacramento e as Missões para Espanha, sendo Santa Catarina recuperada por Portugal (Pesavento, 1992).
} 
condição de estrangeiros, continuaram a agir como emigrantes em potencial, fato que os levou a sair de San Carlos tão logo as condições políticas permitiram.

Considerações finais

Buscando compreender as relações sociais ocasionadas pelos movimentos migratórios, este artigo se dedicou a investigar de modo especial o grupo açoriano conhecido como "Pobladores de San Carlos", discutindo o tensionamento das relações sociais na formação do povoado.

Considerando que Simmel (2005) cita o estrangeiro como a figura que melhor caracteriza a modernidade e Park (1928) indica a migração como o lugar privilegiado para estudar os processos de civilização, os açorianos que povoaram San Carlos, em sua condição de migrantes e estrangeiros, configuram uma arriscada experiência políticosociológica (Fajardo, 1977), reunindo as condições ideais para que se conheça o impacto do processo de mudança ocasionado na época da formação da sociedade moderna.

Embora com o tempo viessem a constituir uma mesma comunidade, pode-se perceber que, durante o período analisado, de 1763 a 1778, o povo açoriano de San Carlos era visto pelos espanhóis da região de Maldonado com distância, como o outro, o diferente, los isleños, o estrangeiro.

Mescla de interação, tensão e conflito, proximidade e distância, autoridade, revolta e submissão, adaptação, ajuste e aceitação, as relações entre açorianos e os demais grupos que povoaram a região, estavam comprometidas pela rivalidade e desconfiança, gerando relações ambivalentes e configurando uma multiplicidade de formas relacionais, que constituíam a própria sociabilidade do povoado.

Finalizando esta pesquisa, convém lembrar, à luz de Simmel (2006) que nenhuma análise pode ser tomada como caminho único para alcançar o conhecimento, estando condicionada pelo ponto de vista do pesquisador, sendo portanto parcial e podendo ser complementada.

\section{Referências}

ALVEAR, Diego de. Diário de la segunda división de límites al mando de d. Diego de Alvear, teniente de navio de la Real Armada. Buenos Aires: Imprenta del Estado, 1837. Disponível em <http://www.biblioteca.org.ar/libros/130485.pdf> Acesso 10 dez 2011. 
ASSUNÇÃO, Fernando O. El gaucho: estudio socio-cultural. Montevideo: Universidad Mayor de la Rep. Oriental del Uruguay,1978. 601p.

. Portugueses en el Río de la Plata. Lisboa: Instituto Camões, 2006.

CÉSAR, Guilhermino. História do Rio Grande do Sul: Período colonial. Porto alegre, Globo, 1970.

CIDADE, Francisco de Paula. Lutas ao sul do Brasil, com os espanhóis e seus descendentes, 1680-1828. Rio de Janeiro: Ministério da Guerra, 1948. 324 p.

DOMINGUES, Moacyr. Portugueses no Uruguai: San Carlos de Maldonado (1764). Porto Alegre: Edições EST, 1994. 98p.

ESTRADA, Marcos M. de. La Villa de San Carlos: Pedro de Cevallos, portugueses y "patagónicos". Montevideo: Ediciones de la Plaza, 2007. Disponível em $<\mathrm{http}$ ://sancarlos.freeiz.com/articuloshistoria/villadesancarlos/> Acesso em 29 set. 2011.

FAJARDO, Florencia Terán. Historia de la ciudad de San Carlos. Orígenes y primeros tiempos. Montevideo: Graf. Oliveras, Roses y Villasmil, 1953. 332 p.

. La Gravitante región de Maldonado. Intendencia Maldonado, 1977. Disponível em $<$ http://www.ejercito.mil.uy/cge/dptoeehh/Libros/Boletin\%20Historico/107\%20Bolet\% C3\%ADn\%20Hist\%C3\%B3rico\%20N\%C2\%BA\%20219\%20-\%20222\%20$\% 20 \mathrm{a} \% \mathrm{C} 3 \% \mathrm{~B} 1 \mathrm{o} \% 2019$ 77.pdf $>$ Acesso em 29 set. 2011.

FREGA, Ana. Pertenencias e identidades em uma zona de frontera. La región de Maldonado entre la revolucion y la invasión lusitana (1816-1820). In: HEINZ, Flávio M.; HERRLEIN JR., Ronaldo (org). Histórias regionais do Cone Sul. Santa Cruz do Sul:EDUNISC, 2003. 464p.

HANSEN, Lucía Basso. Villa de San Carlos: La apacible. Almanaque del Banco de Seguros del Estado. Disponível em < http://www.bse.com.uy/almanaque/Almanaque \%201997/pdf/0\%20-\%20022.pdf > Acesso em 29 set. 2011.

HEINZ, Flávio M.; HERRLEIN JR., Ronaldo (org). Histórias regionais do Cone Sul. Santa Cruz do Sul:EDUNISC, 2003. 464p.

MIRANDA, Orlando. Para ler Ferdinand Tönnies. São Paulo: EdUSP, 1995. 360 p.

MEAD, George. Espíritu, persona y sociedad. Buenos Aires: Paidós Studio, 1973.

NOVAIS, Fernando A. Aproximações: estudos de história e historiografia. São Paulo: Cosac Naify, 2005. 438p.

PAGOLA, Brenda. ... Y ellos le dieron vida. San Carlos: fundadores y vecinos. Montevideo, Uruguai, 2007. 717 p.

PARK, Robert Ezra. Las migraciones humanas y el hombre marginal. Publicado originalmente em American Journal of Sociology, 1928 (maio), no 33, p. 881-893. Disponível em <http://www.ub.edu/geocrit/sn75.htm\#LAS\%20MIGRACIONES\% 20HUMANAS\% 20Y\%20EL\%20HOMBRE>. Acesso em 01 maio 2011.

PESAVENTO, Sandra Jatahy. História do Rio Grande do Sul. Porto Alegre: Mercado aberto, 1992. 142p. 
. Muito além do espaço: por uma história cultural do urbano. In: Estudos históricos: Cultura e história urbana. Rio de Janeiro: vol. 8, nº 16, julho/dezembro.1995. p. 279290.

PINTOS, Aníbal Barrios. Aborígenes e indígenas del Uruguay. Montevideo: Ed. de la Banda Oriental, 1975. 59p.

SEIJO, Carlos. Maldonado y su región. Montevideo: Imp. El Siglo Ilustrado, 1945.

SIMMEL, Georg. Questões fundamentais da sociologia: individuo e sociedade. Rio de Janeiro, RJ: Jorge Zahar, 2006. 119 p.

O estrangeiro. In: RBSE, Revista Brasileira de Sociologia da Emoção. Vol. 4, $\mathrm{n}^{\circ}$ 12, dez de 2005, p. 265-271. Disponível em < http://www.cchla.ufpb.br/grem/SIMMEL. O\%20estrangeiro.Trad.Koury.rbsedez05.pdf $>$ Acesso em 03/07/2011.

TÖNNIES, Ferdinand. Comunidade e Sociedade. In: MIRANDA, Orlando. Para ler Ferdinand Tönnies. São Paulo: EdUSP, 1995. 360 p.

TODOROV, Tzvetan. A conquista da América: a questão do outro. São Paulo: Martins Fontes, 1999. 324p.

WEBER, Max. Economia e Sociedade. Vol. 1. Brasília: UnB, 2000. 464p.

. Max Weber: sociologia. São Paulo: Ática, 1979. 168 p. (Grandes Cientistas Sociais ; n.13. Org. Gabriel Cohn).

WIEDERSPHAN, Oscar Henrique. A colonização açoriana no Rio Grande do Sul. Porto Alegre: EST São Lourenço de Brindes/Instituto Cultural Português, 1979.

Recebido 01/07/2019

Aprovado 24/07/2019 